\title{
Design of a Utility Scale Solar Farm in Saudi Arabia
}

\author{
Hashem Elsaraf ${ }^{1}$, Rehan Khan ${ }^{2}$ and Suboohi Shervani ${ }^{3 *}$ \\ ${ }^{1}$ Department of Engineering \& Applied Science, Memorial University of Newfoundland St. John's, Canada \\ ${ }^{2}$ Someshwaranagar, Jayanagar 1st Block east, Bangalore, Karnataka, India \\ ${ }^{3}$ Department of Engineering \& Applied Science, Memorial University of Newfoundland St. John's, Canada
}

Submission: July 15, 2020; Published: October 06, 2020

*Corresponding author: Suboohi Shervani, Department of Engineering \& Applied Science, Memorial University of Newfoundland St. John's, Canada

\section{Abstract}

Saudi Arabia plans to generate 3.45GW of its energy from renewable sources by 2020 and $9.5 \mathrm{GW}$ by 2023. This project addresses the lack of literature on the design and feasibility of large scale solar in Saudi Arabia. This project went through different design steps with proper justification in designing a $50 \mathrm{MW}$ solar farm. Site selection was carried out using Solar GIS to find the optimum location in terms of irradiance, terrain, proximity to roads and air temperature. Then a PV module was selected from a comprehensive list of all available modules in the market by evaluating the modules based on fill factor, efficiency, degradation rate, power density and module price. PVsyst was then used to simulate the project and the results were displayed and discussed. These results include Loss analysis, energy generated analysis and temperature performance. Next, an economic analysis was carried out which showed that the payback period for this project is 6 years, $315.9 \%$ return on investment (ROI) and 164 million USD net profit by the end of the project lifetime ( 25 years). Lastly, CO2 balance analysis was reported which showed that over the project lifetime Saudi Arabia would be able to save more than 1.68 million tons of $\mathrm{CO}_{2}$ emissions.

Keywords: Fossil fuels; Sustainability; Air temperature; Solar irradiance; Renewable Energy, $\mathrm{Co}_{2}$ emission

\section{Introduction}

Saudi Arabia is planning a grand scheme that would entail a massive shift from the consumption of oil to alternative energy sources, mitigating its dependence on fossil fuels while also working towards fulfilling its commitments to $\mathrm{CO}_{2}$ reduction. The government has established a program named Saudi Arabia's National renewable energy program (NREP). NREP announced that $3.45 \mathrm{GW}$ and $9.5 \mathrm{GW}$ of its energy production would be generated by renewable sources by 2020 and 2023 respectively. A memorandum of understanding has been signed by Saudi Arabia and SoftBank Group Corp. to build a 200 billion USD solar project by 2030 [1]. Moreover, according to the World Economic Forum, it is currently investing around $£ 38$ billion pounds in solar and wind farms [2]. Such ambitious plans require studies to be produced to address the lack of literature on solar PV power plants in Saudi Arabia.

Examples of current solar PV plants (over 1 megawatt) in Saudi Arabia include a 2MW solar plant location in Thuwal, north of Jeddah [3]. A $10 \mathrm{MW}$ carport system in Dhahran [3] and 300MW plant located in Sakaka and Al-Jouf regions, which was established in February 2018 [4]. The potential for large scale solar PV in Different locations in Saudi Arabia was studied in [5].

\section{Background Information}

While Saudi Arabia is a key oil producer and exporter, it is also the largest consumer of energy in the Middle East. By 2032, Saudi Arabia has made plans to increase its electricity generation capacity to 12 Gigawatts in order to fulfill the country's fastgrowing electricity demand. According to British Petroleum (BP) Statistical review of World Energy 2014, Saudi Arabia produced 29.2 billion kilowatt-hours of electric energy in 2013 [6].

During the period between 2006 and 2016, Saudi Arabia's electricity consumption increased by 7.5 to $10 \%$ annually. This swift increase in electricity demand is driven by growth in population, rapidly growing industrial sector due to the expansion of petrochemical cities, elevated need for air conditioning during summer, and strongly subsidized electricity supply rates [6]. According to the Middle East Economic Survey, Saudi Arabia has the largest expansion plan in the Middle East for energy 
production from renewable sources. For this purpose, the King Abdullah City for Atomic and Renewable Energy (K.A. CARE) was established in 2010 in order to build a sustainable future for Saudi Arabia through the inclusion of nuclear energy and renewable energy sources within the local energy system. Saudi Arabia plans by 2032 to add $41 \mathrm{GW}$ of solar power, $18 \mathrm{GW}$ of nuclear power, and
4GW from other renewable sources to expand its electricity supply [6]. IEA is the international energy agency made up of more than 30 countries that produces renewable energy studies. According to one of their studies [7] global solar PV capacity is expected to grow to over 1TW by 2023 (Figure 1).

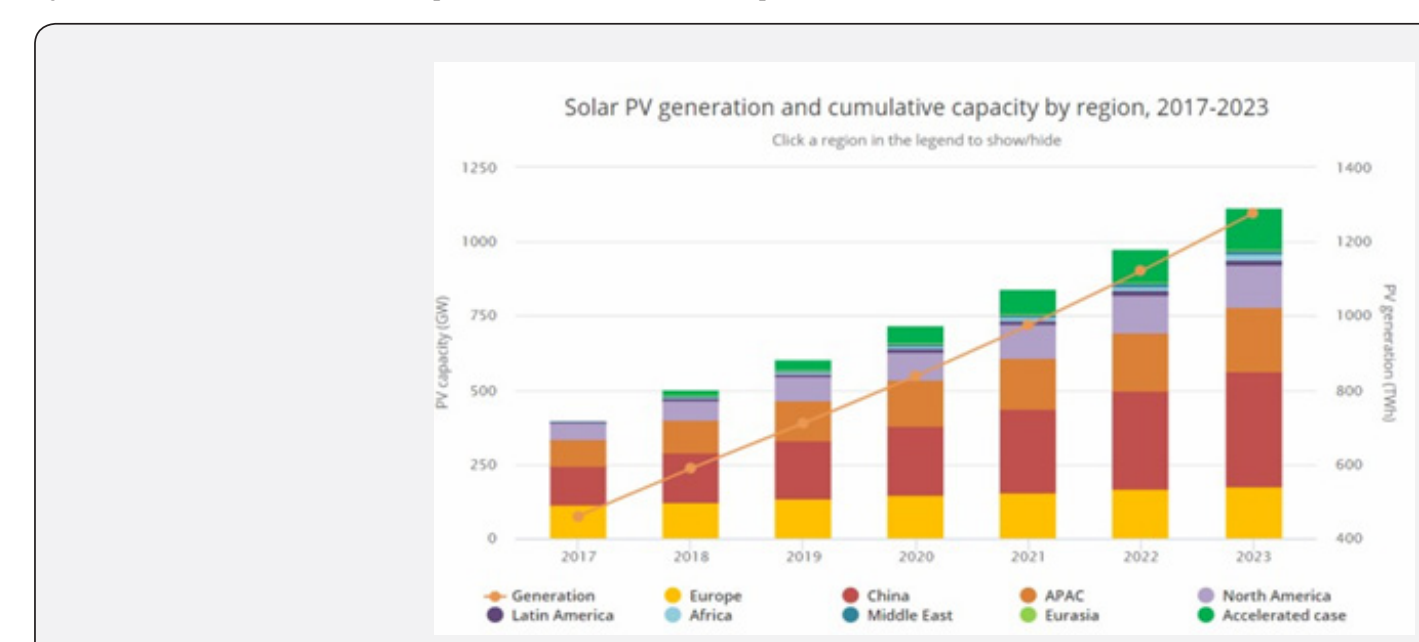

Figure 1: Global Solar PV projections.

Table1: Mena Pv Installed Capacity [8].

\begin{tabular}{|c|c|c|}
\hline Country & PV Capacity (MW) & Year Recorded \\
\hline Algeria & 7.1 & 2010 \\
\hline Bahrain & 5 & 2011 \\
\hline Egypt & 15 & 2012 \\
\hline Iran & 4.3 & 2010 \\
\hline Iraq & 3.5 & 2009 \\
\hline Kuwait & 1.8 & 2010 \\
\hline Libya & 4.8 & 2012 \\
\hline Oman & 0.7 & 2010 \\
\hline Qatar & 1.2 & 2010 \\
\hline Saudi Arabia & 7 & 2013 \\
\hline Syria & 0.84 & 2010 \\
\hline UAE & 1.5 & 2012 \\
\hline Yemen & 1.5 & 2012 \\
\hline Djibouti & 1.4 & 2010 \\
\hline Israel & 269 & 2012 \\
\hline Jordan & 1.6 & 2012 \\
\hline Lebanon & 1 & 2012 \\
\hline Malta & 12 & 2011 \\
\hline Morocco & 15 & 2012 \\
\hline Palestinian & 1 & 2012 \\
\hline Tunisia & 4 & 2012 \\
\hline
\end{tabular}


As can be seen in Figure 1, the share of the Middle Eastland North Africa of solar PV production is almost invisible even though the region enjoys high solar resources and high GDP. According to [8], which was published in 2016, the latest installed PV capacities in the Middle Eastland North Africa as of 2016 are listed in Table 1. The International Renewable Energy Agency (IRENA) is an intergovernmental organization supporting countries in their transition to a sustainable energy future. In 2019, it published a report that included the latest figures for renewables in the gulf region (Bahrain, Kuwait, Oman, Qatar, Saudi Arabia and United
Arab Emirates (UAE)) updated as of the end of 2018 [9].

As can be seen by comparing the two tables; while Bahrain, Oman and Qatar saw a slight increase in their solar capacity, the UAE and Saudi Arabia boomed with over 1000\% increase in their PV capacity in the period between 2012 and 2018. This highlights the countries' increased efforts to meet their sustainability targets by subsidizing renewable energy generation to facilitate their penetration. Figure 2 summarizes the sustainability goals of the different gulf countries [9].

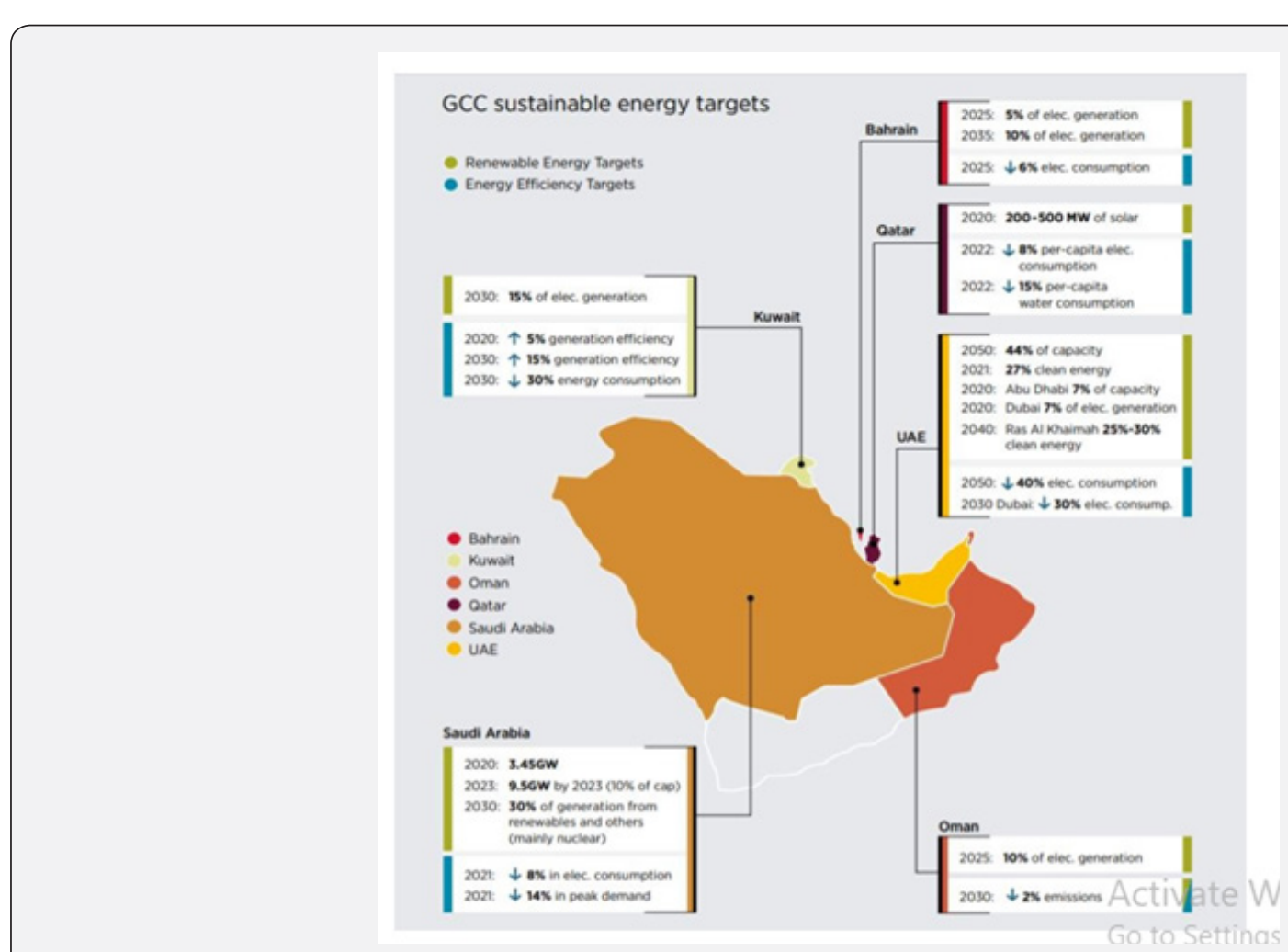

Figure 2: Sustainability goals of the gulf region.

\section{Aims and Objectives}

This project will execute the design and examine the feasibility of a 50 MW solar PV farm in Saudi Arabia. The project aims to study and enumerate the various variables that are of significance to Solar PV design through thorough methodology and research. The project will go through the following phases:
a) Site Selection
b) PV module selection and design
c) Inverter selection
d) Losses analysis

\section{Methodology}

\section{Site selection}

Criteria that determine the optimal site for solar PV farm is obtained from the research paper 'Solar PV power plant site selection using a GIS-AHP based approach with application in Saudi Arabia' by Hassan Z. Al Garni and Anjali Awasthi [5]. The criteria implemented in this project are:
a) Solar irradiance
b) Air temperature
c) Terrain 


\section{d) Road proximity}

To analyze the above criteria, Solargis online tool was used. Solargis tool shows the irradiance level at each point. According to the above-mentionedpaper [5], the author states that the optimal location for solar PV in Saudi Arabia is near Tabuk city.Hence,a location with low terrain and high irradiance level near Tabuk city was searched for. It was found that the global horizontal yearly average irradiance level of $2397 \mathrm{KWh} / \mathrm{m}^{2}$, which is close to shigry as shown in Figure 3.

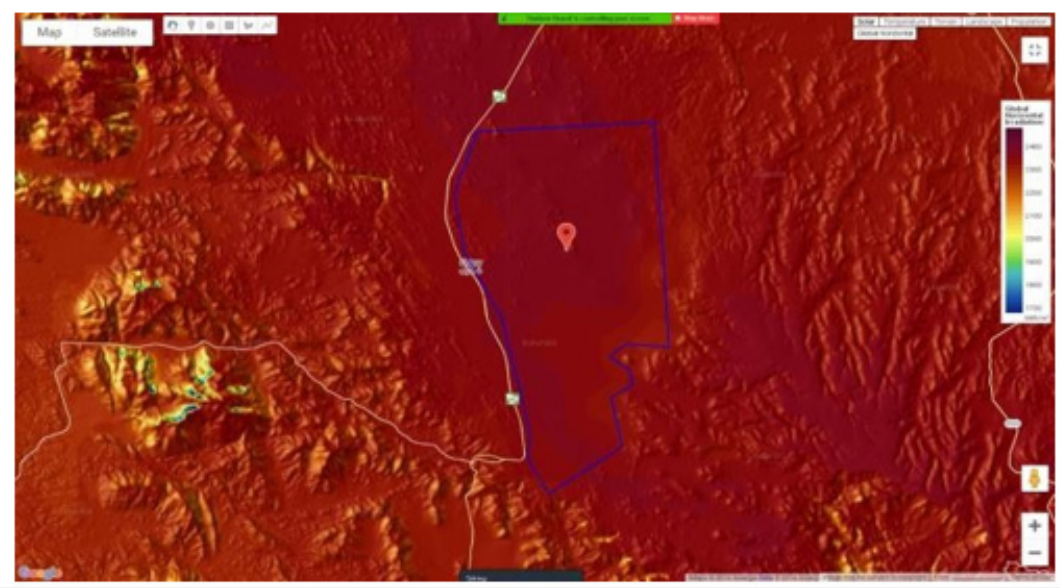

Figure 3: Site selection irradiance.

From Figure 4, the maximum temperature at the costal side of the red sea is around $3^{\circ} \mathrm{C}$ and falls to $28.5^{\circ} \mathrm{C}$ near Tabuk city. In the selected region the temperature lies between $16^{\circ} \mathrm{C}$ and $20^{\circ} \mathrm{C}$ annual average temperature and since the Standard Test Conditions (STC) temperature for PV panels is $25^{\circ} \mathrm{C}$ and as the temperature decreases the efficiency increases [10]. It can be expected that the output of the solar farm will increase in winter and decrease slightly in summer due to the increased ambient temperature.
$V_{o c, \bmod }=$ Temp.coeff.X $\left.\left(\operatorname{TSTC}^{O}{ }^{O} \mathrm{C}\right]-T \bmod \left[{ }^{o} C\right]\right)+V_{o c, \text { rated }}[V]$

Where

a) $\mathrm{V}_{\mathrm{oc} \text { mod }}$ is the open circuit voltage at current temperature.

b) $\operatorname{TSTC}\left[{ }^{\circ} \mathrm{C}\right]=$ temperature at standard test conditions $, 25^{\circ} \mathrm{C}, 1000 \mathrm{~W} / \mathrm{m}^{2}$ solar irradiance.

c) $\operatorname{Tmod}\left[{ }^{\circ} \mathrm{C}\right]=$ module temperature.

d) $V_{o c \text {, rated }}$ is the open circuit voltage at STC.

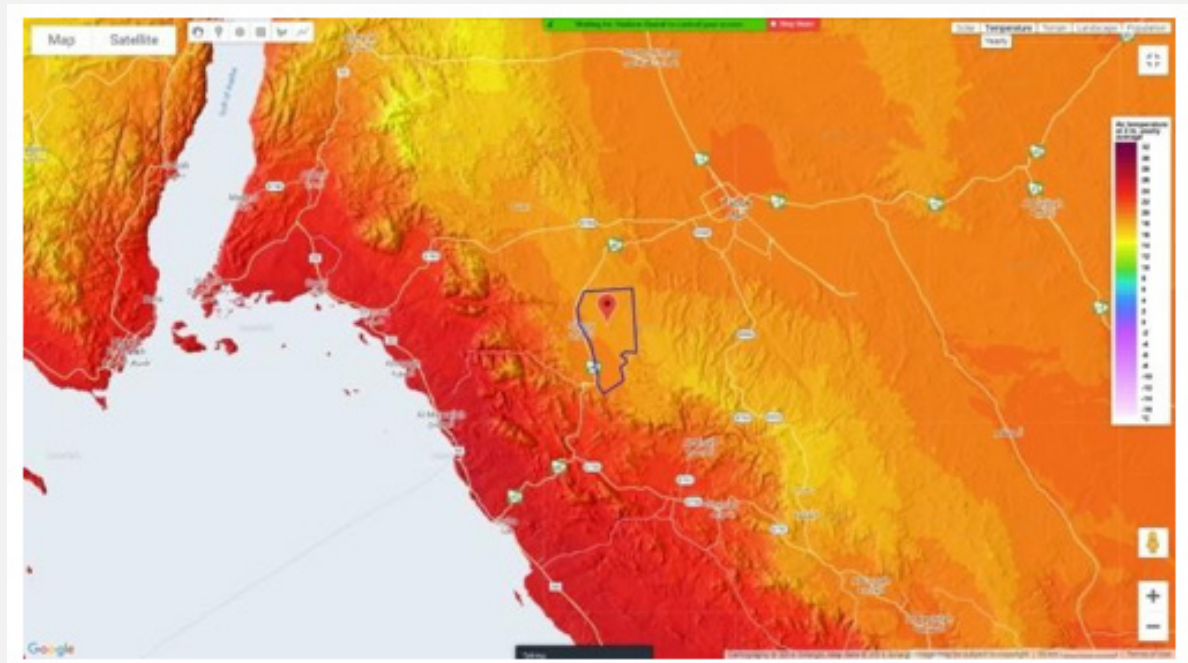

Figure 4: Site selection temperature. 
From this equation, it is evident that as the module temperature decreases below STC levels the open circuit voltage of the module increases. The module temperature is affected by the ambient temperature. As the ambient temperature decreases, it further increases the power curve as can be seen in Figure 5. The reason the average annual temperature is low in this area could be due to the high elevation of the land (1092m) (Table 2).

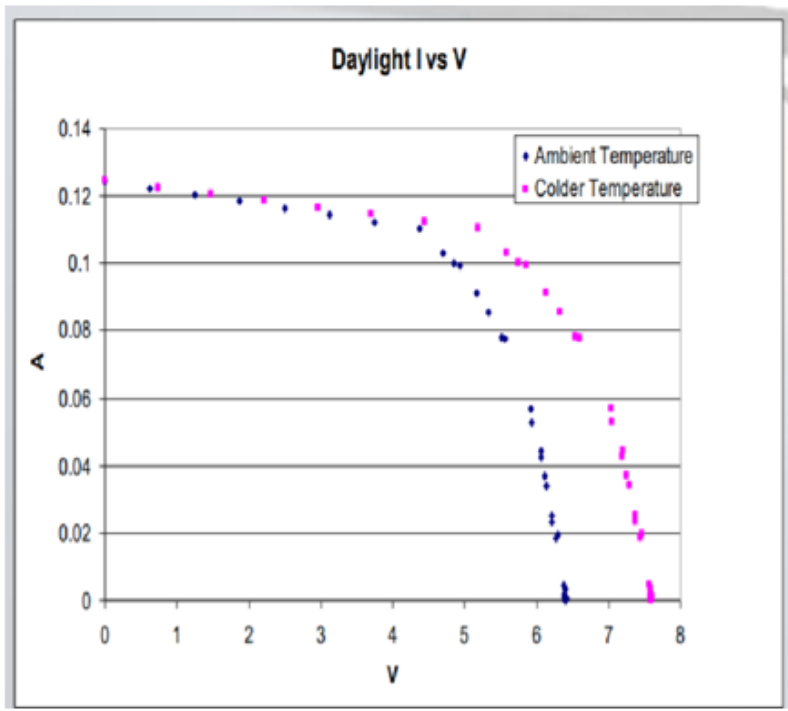

Figure 5: IV power curve of PV cell. Power is greater at lower temperatures.

Table 2: Gulf Region Pv Capacity by the end of 2018 [9].

\begin{tabular}{|c|c|}
\hline Country & PV Capacity (MW) \\
\hline Bahrain & 5 \\
\hline Kuwait & 19 \\
\hline Oman & 8 \\
\hline Qatar & 5 \\
\hline Saudi Arabia & 89 \\
\hline UnitedArab Emirates & 487 \\
\hline
\end{tabular}

For the ease of installation of the large scale, solar, flat terrain that is near to roads is required. As can be seen in Figure 6. The area selected is on a flat area near to the road this minimizes land leveling and transportation costs. The area is sparsely vegetated which means it requires minimum land clearing. The total area of the selected land is $494.8 \mathrm{~km}^{2}$ it is expected that only a small fraction of this area will be used for the project. The slope of the area is minimal at $0.7^{\circ}$ as can be seen in Figure 7 . Figure 7 also shows important figures in the right panel under the title "Site info".

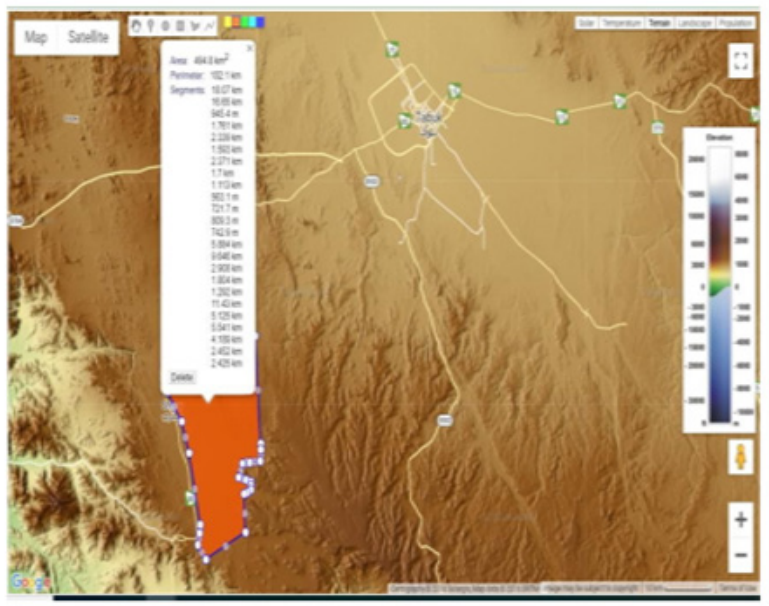

Figure 6: Site selection terrain. 


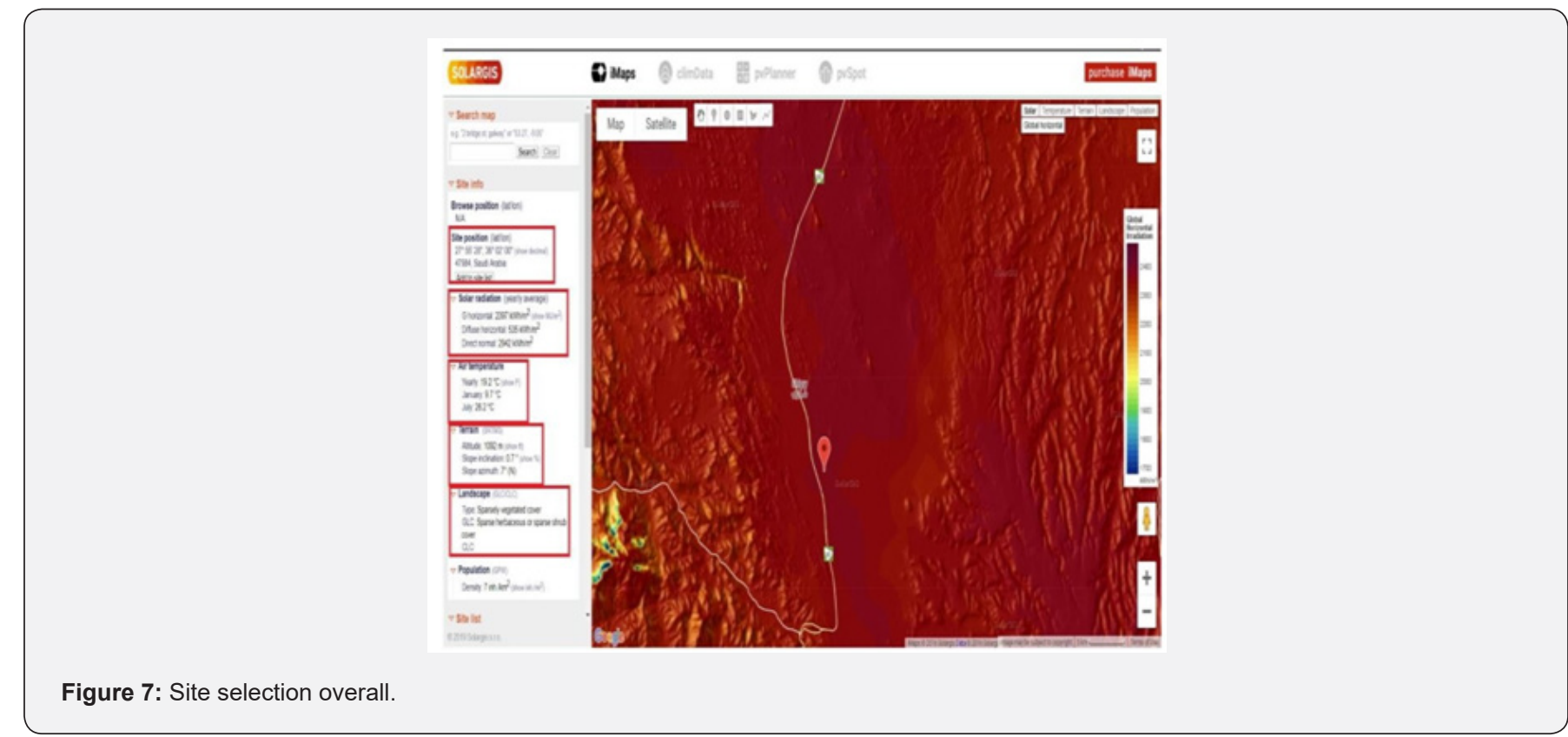

\section{PV Module Selection}

In order for optimum PV module selection, different selection parameters are covered in this section which include fill factor, efficiency, degradation rate, power density and module price. By studying these parameters, an informed decision can be made on which PV module is optimum for this design.

\section{PV Module Selection Criteria}

\section{Fill Factor}

According to [11] the fill factor is a measure of the squareness of the I-V characteristics of the solar cell. The factors affecting the fill factors are:

a) The series resistance of the solar cell

b) The parallel resistance of the solar cell

c) The recombination current in the space charge region of the cell

d) $F=\frac{\text { ThR } R_{m} \text { reverse saturation current of the junction }}{\left(V_{o c} I_{s c}\right)}$

Where:

$\mathrm{P}_{\mathrm{m}}$ is the maximum output power

$\mathrm{V}_{\text {oc }}$ is the open circuit voltage

$\mathrm{I}_{\mathrm{sc}}$ is the short circuit current

Ideally, FF = 1, The fill factor decreases as the cell temperature increases. Decreases in fill factor may indicate problems with the cell. A good fill factor based on [11] starts at 0.7.

\section{Efficiency}

Efficiency is another measure of PV cell that is sometimes reported. Efficiency is defined as the maximum electrical power output divided by the incident light power. Efficiency is commonly reported for a PV cell temperature of $25^{\circ} \mathrm{C}$ and incident light at an irradiance of $1000 \mathrm{~W} / \mathrm{m}^{2}$ with a spectrum close to that of sunlight at solar noon. An improvement in cell efficiency is directly connected to cost reduction in photovoltaic systems. [11] Maximum efficiency is the ratio between the maximum power and the incident light power, given by:

$\mu_{\max }=\frac{P_{\max }}{P_{\text {in }}}-\frac{I_{\max } V_{\max }}{A G_{T}}$

(3)

Where
a) A = PV cell area $\left(\mathrm{m}^{2}\right)$
b) GT $=$ solar insolation over the cell $\left(\mathrm{Watt} / \mathrm{m}^{2}\right)$

\section{Degradation rate}

The degradation rate of solar PV is the loss of efficiency every year. Degradation is strongly correlated with weather conditions i.e. panels in harsh (either too hot or too cold) climates suffer higher degradation than panels in moderate climates [12]. According to the national renewable energy laboratory [13], which is a U.S. government associated body that examined the long-term degradation of multiple PV panels. They found that panels made prior to the year 2000 often achieved less than 1\% degradation and that modern panels achieve even lower. Old monocrystalline silicon achieves less than $0.5 \%$ per year degradation rate and modern less than $0.4 \%$. This means that panels made after the year 2000 should produce $92 \%$ of its original power after 20 
years. In [14] the authors examined 11000 degradation rates from 200 studies and analysed them. They found that the median degradation rate for crystalline silicon PV was $0.5-0.6 \%$ per year with a mean of $0.8-0.9 \%$ per year. Micro silicon and hetero interface PV exhibited a 1\%/ year degradation.

\section{Power density}

Power density is an important factor to consider since at higher power densities more energy is produced using less area.

Power $_{\text {density }}=\frac{P_{\max }}{\text { Area }}\left(\frac{\text { Watt }}{m^{2}}\right)$

\section{Analysis}

To select the most optimum PV module and manufacturer a list of all available PV modules was obtained from [15]. The excel file contained approximately 22000PV modules updated as of April 2019 and categorized under different performance parameters. Building integrated modules and modules that produce AC power (micro inverter) were omitted.

Initially $\mathrm{B}_{\mathrm{Voc}}$ was looked at as it is the temperature coefficient. The module, which performs best under hot climate, was found to be REC260TP, which is made by REC Solar with a temperature coefficient of $-0.03 \%$ /degree C. However, since the temperature in the selected site is very mild $\left(16^{\circ} \mathrm{C}\right.$ to $20^{\circ} \mathrm{C}$ annual average temperature) this parameter was disregarded in favor of fill factor and efficiency.

The fill factor was not provided in the file produced by go solar california and had to be manually inputted. The fill factor equation was $S^{*} R$

$\overline{Q^{*} P}$

Where $S$ is $V_{\text {pmax }}$ R is $I_{\text {pmax }} \mathrm{Q}$ is $\mathrm{V}_{\text {oc }}$ and $\mathrm{P}$ is $\mathrm{I}_{\text {sc }}$. The best module with the highest fill factor was China Sunergy (Nanjing) CSUN275$60 \mathrm{P}$ with a fill factor of 0.97377 however; this specific module was not available on PVSYST.

The next parameter in consideration was efficiency, which also had to be manually added. The equation for which was

\section{$=\frac{E}{\left(1000^{*} A G^{*} A F\right)^{*} 100}$}

where $\mathrm{E}$ is the $\mathrm{P}_{\text {max }^{\prime}} \mathrm{AG}$ is the longside and $\mathrm{AF}$ is the shortside. The best performing module in terms of efficiency was LG370Q1C-A5, which is manufactured by LG electronics with an efficiency of $22.13437 \%$ however; this module was also not available on PVSYST.

Efficiency: PV modules ranging between 19.5 - 22 percent efficiency are considered and sorted out from highest to lowest.

Fill Factor: PV modules ranging between $0.72-0.79$ are considered and sorted out from highest to lowest after efficiency sorting.
Power Density (Watt/m²): Size of the PV is considered such that it gives out maximum power within that size of the module. Hence, Pmax divided by the area of the panel (short side * long side) is determined. (Equation 4).

Degradation rate: The latest commercial SunPower solar PV panels such as (SPR-X22-360-COM) has a degraded output of $92 \%$ and greater after 25 years, LG's latest solar PV panel variants called 'Neon R' gives out $88.4 \%$ of the output after 25 years based on the data sheets provided by SunPower and LG [16,17].

The top 5 choices after filtering and sorting were:

a) LG370Q1C-A5

b) SPR-X22-360-COM

c) SPR-X22-359

d) SPR-X22-475-COM

e) LG365Q1C-A5

Prices for the modules were hard to obtain which turned consideration from 5 to 3 options. LG370Q1C-A5 was available at 0.95 USD/Watt, which makes the total panel, cost equal to 47.5 million USD for a 50 MW project (retail price). [18] SPR-X22-360COM was available at $1.74 \mathrm{USD} /$ Watt which makes the total panel cost equal to 87 million USD for a $50 \mathrm{MW}$ project (retail price) [19]. LG365Q1C-A5 was available at 0.91 USD/Watt which makes the total panel cost equal to 45.5 million USD for a $50 \mathrm{MW}$ project (retail price) [20].

The final comparison between LG and SunPower yielded the following conclusions

a) They are both high in efficiency and fill factor 2- LG is cheaper than SunPower

b) SunPower has a lower degradation rate than LG

c) LG is a more established manufacturer and so more likely to uphold the warranty

Since the project lifetime will be set as 25 years LG is picked as the more favorable manufacturer due to the lower price point of its product. Even though LG365Q1C-A5 will take more area than LG370Q1C-A5 the difference in area is small while there is 2 million USD difference in price and so LG365Q1C-A5 is chosen as the optimum PV module.

The total area that will be occupied by the plant was found to be $=0.23 \mathrm{Km}^{2}$ the equation to find the plant area is:

Area required $=\left(\frac{\text { total power }}{\text { individual cell rated power }}\right) *($ cell length $*$ cell width

The value of the area obtained was later verified through PVsyst. Since the area selected in the previous section was $494.8 \mathrm{~km}^{2}$. there is more than enough space to create the project practically. The project will take up $0.046 \%$ of the proposed area. 


\section{Supporting structure}

For this project, supporting structures provided by Soeasy (Xiamen) Photovoltaic Technology Co., Ltd [21]. The reason this company's product was chosen is because it is reasonably priced, and the company has high reputation on alibaba.com. The total cost of the structure is 4.61 million USD

\section{Inverter selection}

A full list of inverters available in the market was obtained from [22]. The list contained a column titled microinverters with values $\mathrm{N}$ for No $\mathrm{Y}$ for yes and Blank. The list was filtered so that only central inverters that are not micro inverters were shown. Then operating power was filtered so as to minimize the number of inverters used. Inverters with a power of 1.5MW upwards were chosen. Sunny central SC- 2200-Us inverter manufactured by SMA was chosen. It has $2200 \mathrm{kw}$ power, 570 minimum voltage, 950 maximum voltage and 665 nominal voltage. Initially Sunny central $3000 \mathrm{kw}$ was chosen, but it generated some errors on PVsyst such as increased overload loss and higher Pnom ratio which, went down as the number of inverters increased. However, another error displayed as "the array Voc at $-10 \mathrm{C}$ is greater than the absolute system voltage allowed for this module" persisted even as the number of inverters was increased making this module not compatible with this application.

The price of the inverter was not directly obtainable. So, the per watt cost of a $700 \mathrm{kwatt}$ sunny central inverter was found to be 0.18 USD/Watt. A trend can be noted that as the power output of the inverter increases, the per watt cost of the inverter decreases. It could very well be the case that $2200 \mathrm{KWatt}$ inverter is priced lower than $0.18 \mathrm{USD} /$ Watt but since the exact price could not be found, $0.18 \mathrm{USD} /$ Watt is taken as the unit price. For a 44 Mega Watt system the price of the inverters is $\left(44^{*} 10^{\wedge} 6\right) * 0.18$ or 7.92 million USD [23].

\section{Balance of system (BOS) components}

a) AC and DC cables

b) Fuses or over current protection units

c) AC and DC switches

d) Array junction box or combiner box

e) Connectors

f) $\mathrm{AC}$ and $\mathrm{DC}$ surge protection devices

g) Earthing system

h) Lightning protection system (LPS)

i) Special connectors for PV modules, string cables and inverters

j) Supporting structures

k) Land cost

\section{l) Labour cost}

Land cost is not included since it is assumed based on the current political situation that the government of Saudi Arabia will carry out this project so no land capital will be allocated. Labour cost is cheap in Saudi Arabia compared to the developed countries and inverter and supporting structure costs have already been included elsewhere. Therefore, the lowest figure for BOS found in a credible source shall be taken. In [24] IRENA states that the lowest cost of BOS is $20 \%$ of the total cost. Based on the previous justification this figure shall therefore be used for this project.

\section{PVsyst steps}

PVsyst simulation tool was used to design a solar PV farm in the selected location. Meteorological data from meteonorm was used and the respective file was created in PVsyst. By entering the site coordinates, metrological data was obtained with PVsyst and a new location was created since shigri was not one of the locations registered on PVsyst. In PVsyst, under project design a grid-connected system is selected. The project is named Neom; a new site file is created by selecting the site on the interactive map and clicking on import, which provides the details of the site automatically. Then, the meteorological data is imported from meteonorm 7.2 and the file is saved and named shigiri. The project is saved to proceed with the design.

In the orientation tab, orientation of the PV system was determined using the optimization tool within PVsyst. 'Fixed tilted plane', is selected and the plane is tilt of $30^{\circ}$ was obtained and kept the orientation of the panels to perfect south (i.e., Azimuth $=0^{\circ}$ ) since axis tracking would incur additional cost and add complexity beyond the scope of this work. Tilt angle of $30^{\circ}$ was chosen based on the angle optimization tool in PVsyst as can be seen in Figure 8. The optimum plane orientation in winter, summer and yearly is 0 degrees and the optimum tilt in winter, summer and yearly is 50,0 and 30 degrees, respectively. Since 30 degrees is the optimum yearly tilt, it was chosen. 0 degree was chosen for the plane orientation. In [25] the authors stated that the optimum tilt angle based on a previous study for panels facing the south was equal to the latitude of the location. This enables the system to achieve at least $98 \%$ of its performance. Since the latitude of this project's location is $27.92^{\circ} \mathrm{N}$ and azimuth angle is $0^{\circ}$ (facing south). Choosing $30^{\circ}$ as the tilt angle is further justified as a good choice.

Under the system tab, the planned power is initialized to 50,000KWp. The chosen PV module 'LG365Q1C-A5' and the inverter 'SMA SC2200' are selected. Max power at the $25^{\text {th }}$ year was calculated as the efficiency at the $25^{\text {th }}$ year $*$ the max power (50MW). Dc to Ac ratio was calculated with 50MW/Max power at the $25^{\text {th }}$ year and was 1.13 . The selections were set in PVsyst and allowed it to size automatically, since some errors with under sizing were found, the number of inverters was increased to 20 and adjusted the number of PV modules in series and parallel 


\section{Trends in Technical \& Scientific Research}

to 20 and 6800 respectively with total number of PV modules equaling 136000. The results met the desired expectations of DC/
AC ratio of 1.13 and with minimum overload loss of $0.5 \%$, with no errors. As can be seen in Table 3 .

Table 3: System parameters.

\begin{tabular}{|c|c|c|}
\hline Parameter & Value & Parameter \\
\hline No. of modules & 136000 & No. of strings \\
\hline Module area & $234899 \mathrm{~m} 2$ & Tilt angle \\
\hline No. of inverters & 20 & Azimuth angle \\
\hline Nominal PV power & $49640 \mathrm{~kW}$ & orientaion \\
\hline Max. PV power & $51230 \mathrm{~kW}$ & Overload loss \\
\hline Nominal AC power & $44000 \mathrm{~kW}$ & Pnom ratio \\
\hline Modules in series & 20 & Inverter voltage range \\
\hline
\end{tabular}

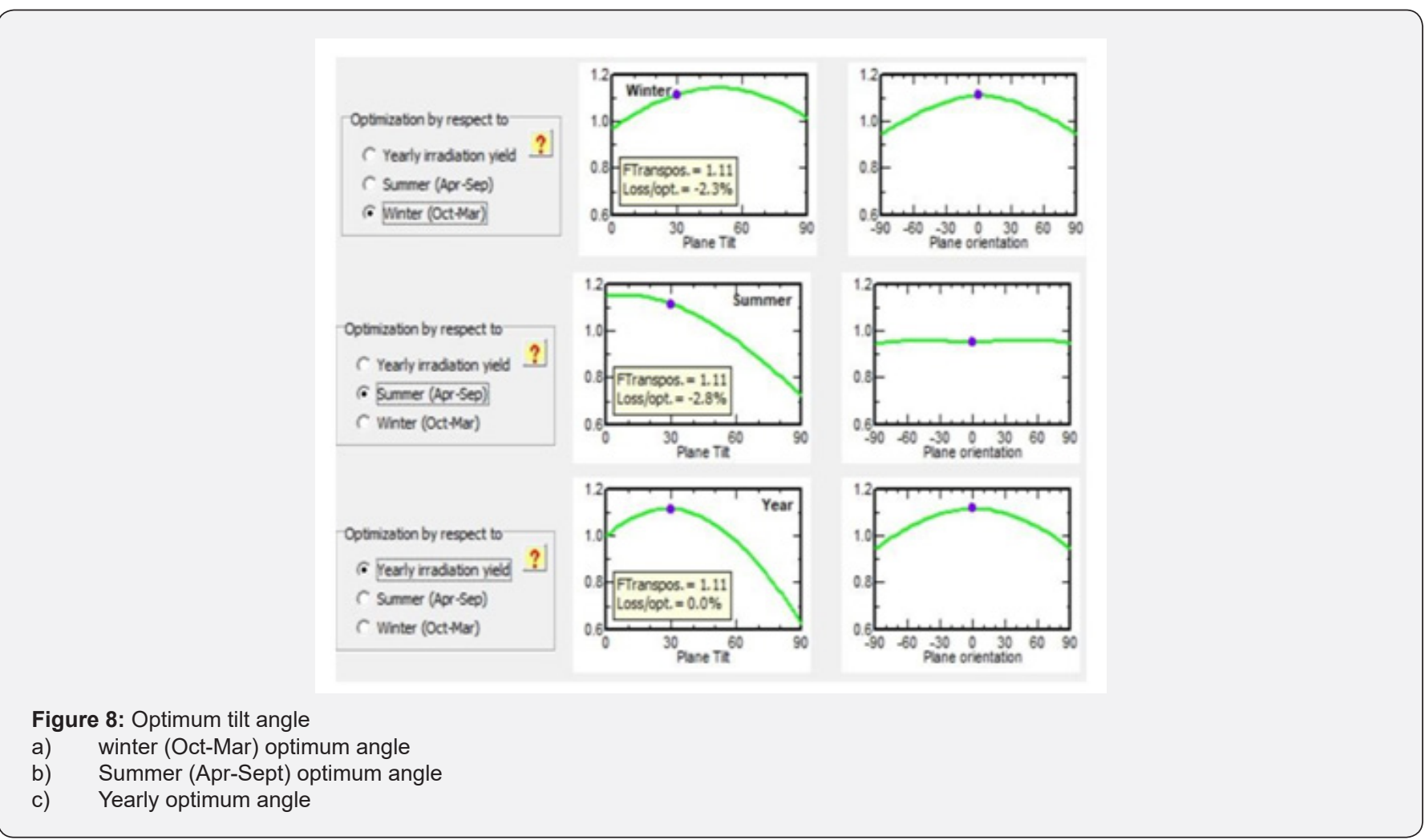

\section{Results and Discussion}

\section{Losses Analysis}

\section{Auxiliaries energy losses}

In the Loss tab, continuous auxiliary loss for 20 inverters are $162 \mathrm{KW}$ from the datasheet, the threshold inverter output is set to $40 \mathrm{MW}$. Night standby loss is $6 \mathrm{KW}$ from the datasheet as can be seen in Table 4. Auxillary losses include energy lost in fans, air conditioning, monitoring and other electronics or lighting [26].
Table 4: Auxillaries Energy Losses.

\begin{tabular}{|c|c|}
\hline Parameter & Value \\
\hline Continuous auxiliary losses (fans, etc.) & $162 \mathrm{~kW}$ \\
\hline ..from inverter output power threshold & $40000 \mathrm{~kW}$ \\
\hline Proportional to the inverter output power & $0 \mathrm{~W} / \mathrm{kW}$ \\
\hline From inverter output power threshold & $0 \mathrm{~kW}$ \\
\hline Night axillaries losses & $6.0 \mathrm{~kW}$ \\
\hline
\end{tabular}




\section{Other Losses}

\section{Array Thermal losses}

The following sections explain how PVsyst calculate thermal losses. The field thermal behavior has a big effect on the electrical performance of the PV cell. It is calculated as the difference between the ambient and cell temperatures. It is given as the following:

$$
\begin{aligned}
& U .(\text { Tcell }- \text { Tamb })=\alpha \times(1-\eta) \\
& \text { Tcell }=\text { Tamb }+\frac{1}{U}(\alpha . \text { Ginc. }(1-\eta))
\end{aligned}
$$

So, where:

a) Tamb is the ambient temperature of the site.

b) Ginc is the irradiance on the module or PV array.

c) Tcell is the cell temperature.

$\alpha$ is the absorption coefficient of solar irradiation (1 reflection). The usual value of the Absorption coefficient $\alpha$ is 0.9 . It is eventually modifiable in the PV module definition dialog. $\eta$ is the PV efficiency which is calculated according to the operating conditions of the module. Otherwise, it is taken as $10 \%$. The U-valueis the thermal loss factor, which can be split into a constant component $\mathrm{Uc}$, and a factor proportional to the wind velocity $\mathrm{U} v$. These U-factors depend on the mounting mode of the modules (sheds, roofing, facade, etc...).

$$
U=U c+U v \times v
$$

(Ucisin $\left[\mathrm{W} / \mathrm{m}^{2} \cdot \mathrm{k}\right], \mathrm{Uv}$ is in $\left[\mathrm{W} / \mathrm{m}^{2} \cdot \mathrm{k} / \mathrm{m} / \mathrm{s}\right]$ and $\mathrm{v}=$ wind velocity in $[\mathrm{m} / \mathrm{s}])$.

\section{Determination of the U-parameters}

In the absence of reliable measured data, PVsyst proposes default values without wind dependency (i.e. assuming an average wind velocity). For free-standing systems (with air circulation all around the collectors), according to measurements on several installations: $\mathrm{Uc}=29 \mathrm{~W} / \mathrm{m}^{2} \cdot \mathrm{k}$ and $\mathrm{Uv}=0 \mathrm{~W} / \mathrm{m}^{2} \cdot \mathrm{k} / \mathrm{m} / \mathrm{s}$

Therefore, for fully insulated backside (no heat exchange at the backside, only one side contribution to the convection heat exchange), the $U$ value should be divided by $2: \mathrm{Uc}=15 \mathrm{~W} / \mathrm{m}^{2} \cdot \mathrm{k}$ and $\mathrm{Uv}=0 \mathrm{~W} / \mathrm{m}^{2} \cdot \mathrm{k} / \mathrm{m} / \mathrm{s}$ For intermediary cases (semi-integration, air duct below the collectors), the value should be taken between these 2 limits, but preferably lower than $22 \mathrm{~W} / \mathrm{m}^{2} \cdot \mathrm{k}$ as the air heat removing is often not very efficient. The default value proposed by PVsyst for any new project is: $\mathrm{Uc}=20 \mathrm{~W} / \mathrm{m}^{2} \cdot \mathrm{kandUv}=0 \mathrm{~W} /$ $\mathrm{m}^{2} \cdot \mathrm{k} / \mathrm{m} / \mathrm{s}$.

If reliable wind velocity data is present Pvsyst suggests inserting it. some users have proposed, when using standard meteo values such as those in the US TMY2 data and free- standing system, the following $\mathrm{U}$-values should be used: $\mathrm{Uc}=25 \mathrm{~W} / \mathrm{m}^{2} \cdot \mathrm{kand}$ $\mathrm{Uv}=1.2 \mathrm{~W} / \mathrm{m}^{2} \cdot \mathrm{k} / \mathrm{m} / \mathrm{s}$. Assuming an average wind velocity of
$3 \mathrm{~m} / \mathrm{s}$, this corresponds to $\mathrm{U}=28.6 \mathrm{~W} / \mathrm{m}^{2} \cdot \mathrm{k}$, close to the PVsyst standard value of $29 \mathrm{~W} / \mathrm{m}^{2} \cdot \mathrm{k}$.

Based on the previous analysis given by Pvsyst and since no accurate wind data was obtained, this project will use Uc $=29 \mathrm{~W} / \mathrm{m}^{2} \cdot \mathrm{k}$ and $\mathrm{Uv}=0 \mathrm{~W} / \mathrm{m}^{2} \cdot \mathrm{k} / \mathrm{m} /$ ssince this design involves a free standing system with full air circulation on both sides of the module. Upon switching the Uc value from 20 to $29 \mathrm{~W} / \mathrm{m}^{2} \cdot \mathrm{k}$. a system error showed up saying the inverters were undersized. By increasing the number of inverters from 20 to 21 the output energy increased from 107723 MWh to 108138 MWh by increasing the number of inverters further to 22 the output energy became $108280 \mathrm{MWh}$. To evaluate the efficacy of this increase; the average energy generated by an inverter that is part of the first 20 inverters is:

$$
\frac{\text { Total Energy }}{\text { Number of inverters }}=\frac{107723}{20}=5386.15 \mathrm{MWh} / \text { inverter }
$$

By adding another inverter, the energy per inverter is:

$$
\frac{\text { Energy }_{21 \text { inverters }}-\text { Energy }_{20 \text { inverters }}}{\text { Change in number of inverters }}=415 \mathrm{MWh} / \text { inverter }
$$

Further increasing the number of inverters to 22 results in a $142 \mathrm{MWh} /$ inverter increase. Since the increase in energy for 21 inverters and 22 inverters are very low relative to the average increase of the first 20 inverters it is decided that only 20 inverters will be used even if the system shows an error saying the inverter is undersized. This will reflect positively on the economics of this project.

\section{Soiling Losses}

Performance variation due to environment factor like dirt is something difficult to predict and is subjected to the surrounding environment. Residential regions and regions which has medium rain falls has almost negligible soiling factor or less than $1 \%$. Industrial region contributes high percentage for the soiling losses. It has been reported that the effects of metallic dust near railways, which causes further pollution, contributes a high percentage of soiling losses. Areas with a lot of birds suffer an increased yet small soiling loss of $2 \%$ due to bird droppings which do not get washed away by rain. Since this project is in an arid desert region, soiling coefficient has been taken as $3 \%$ to account for heavy dust and relatively little rain.

\section{PVsyst Loss Diagram}

As can be seen from Figure 9 the energy density at the collectors is $2423 \mathrm{kWh} / \mathrm{m}^{2}$ after IAM factor losses and soiling losses, $21.15 \%$ of this energy is utilized by the PV array (at STC). The energy output from the PV array is $110482 \mathrm{MWh}$ at Maximum Power Point (MPP). The energy output from the inverter to the grid is 107723 MWh. The loses breakdown is as follows: the highest losses were $5.77 \%$ due to thermal losses followed by $3.0 \%$ losses due to soiling. $1.22 \%$ ohmic wiring losses (at STC). $1 \%$ module mismatch losses. $0.8 \%$ Module quality losses while the lowest losses were $0.10 \%$ losses due to strings mismatch 
losses. In Figure 10, the amount of useful energy produced (red), the amount of energy lost due to PV-array (blue) and system losses (green) are displayed. it can be observed that during the winter months (November, December, January and February) the collection losses are low while the system losses are high while the opposite is true for summer (June and July). Overall, the amount of useful energy harvested every month varied. Reaching its peak in March and dipping to its lowest value in January.

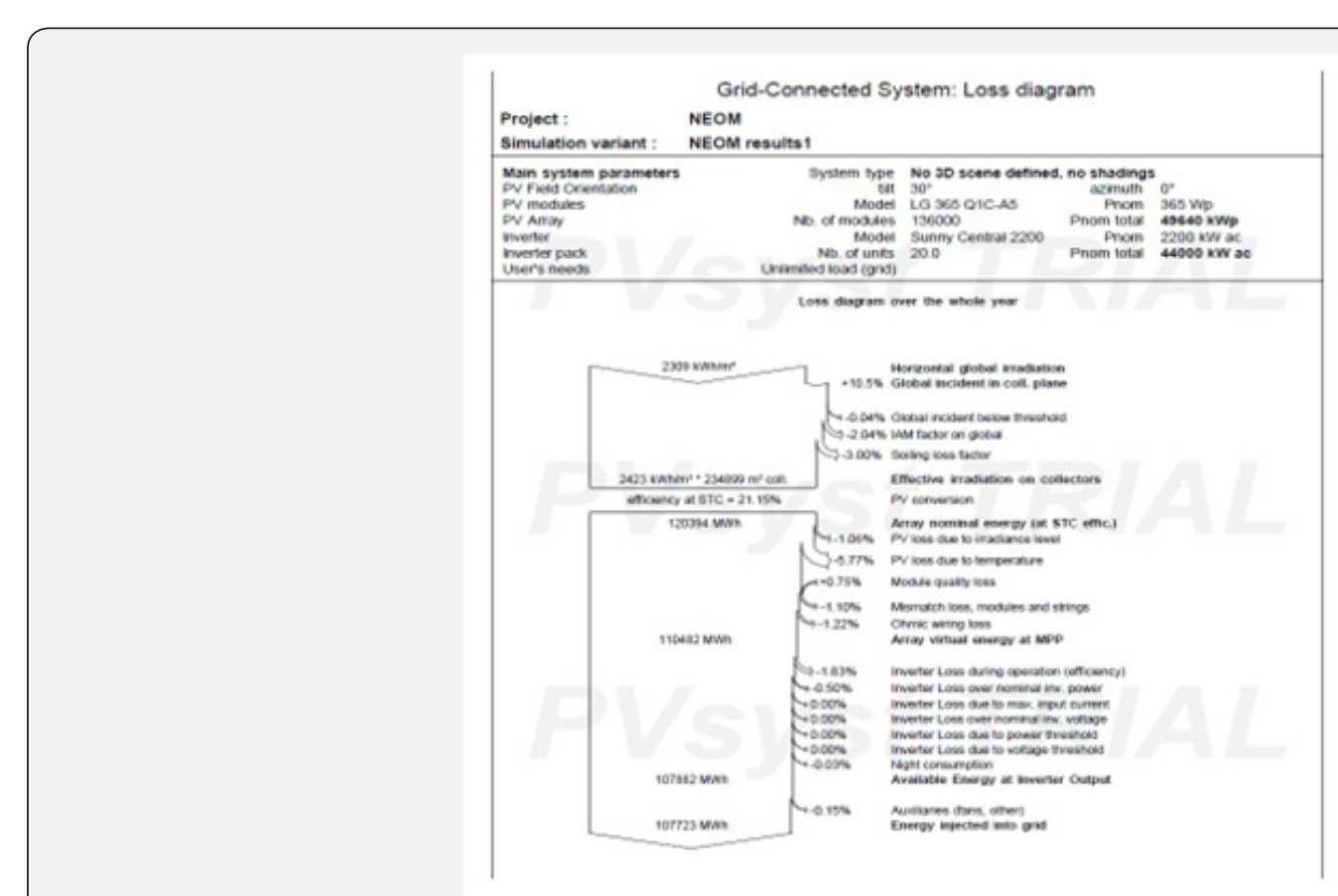

Figure 9: Losses breakdown.

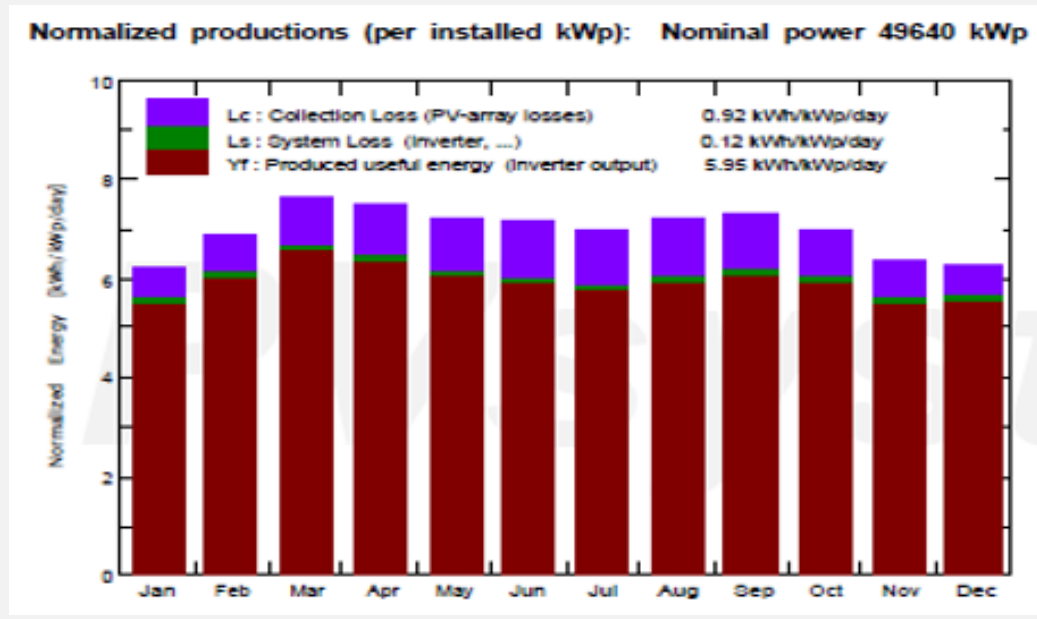

Figure 10: Normalized energy production.

As can be seen from Figure 11 the energy injected into the grid throughout the whole year is almost within the same range, that is to say, there is no large difference between the energy produced in summer over energy produced in winter. The reason for that could be due to the tilt angle being chosen for year-round optimum (Figure 8-c) instead of summer optimum. The month that showed the most energy production is March and the month with the least energy production is November. Figure 12a shows the average module temperature during running for every month. January had the lowest temperature of around $27^{\circ} \mathrm{C}$ and August the highest of around $46^{\circ} \mathrm{C}$. Figure $12 \mathrm{~b}$ shows the ambient temperatures throughout the year. By comparing the two graphs, a direct correlation between average monthly ambient temperatures and average monthly module temperatures can be observed. 


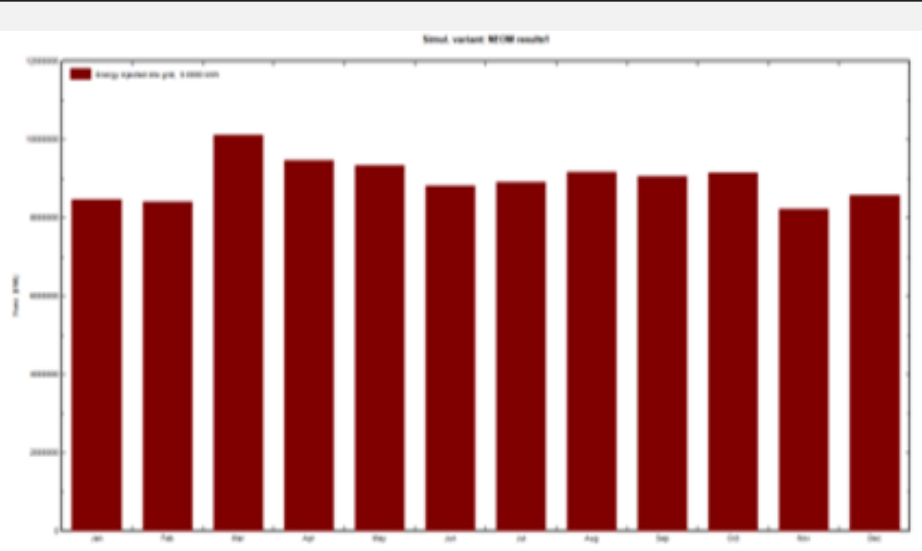

Figure 11: Energy injected into the grid.

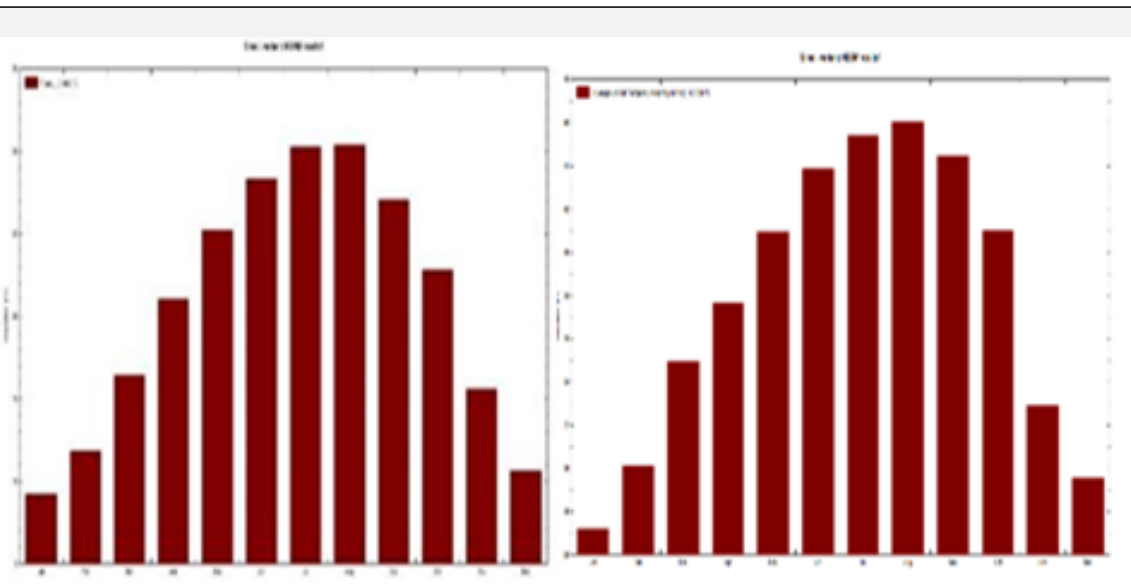

Figure 12: a) Average monthly module temperature. b) Average monthly ambient temperature.

Figure 13 shows the array temperature vs the effective global irradiance in the current project. It can be compared to similar plots from other studies. Such as the one in Figure 14 which was obtained from [27] and was conducted in Malaysia. By comparing the two plots, it can be observed that the system in this project achieved lower module temperatures at higher irradiance. This can be due to the ambient climate reducing the module temperature, a higher quality PV module being used resulting in lower heat losses or due to geographical and meteorological differences between the two locations.

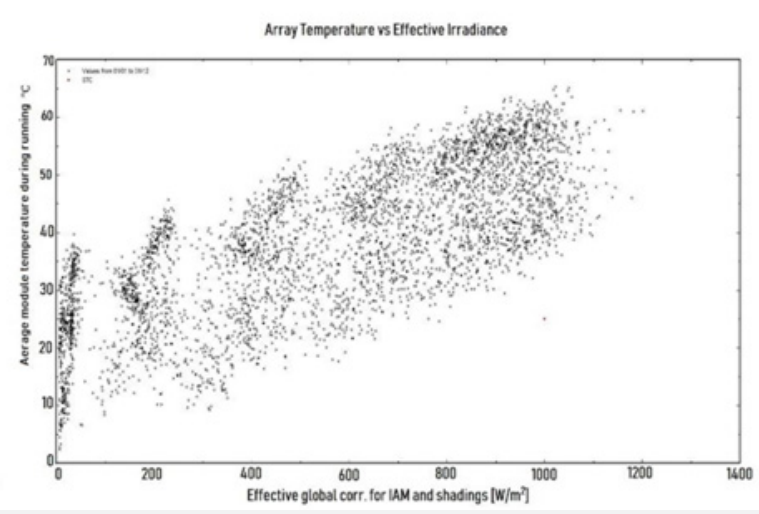

Figure 13: Irradiance vs Module temperature (for proposed system) scatter plot. 


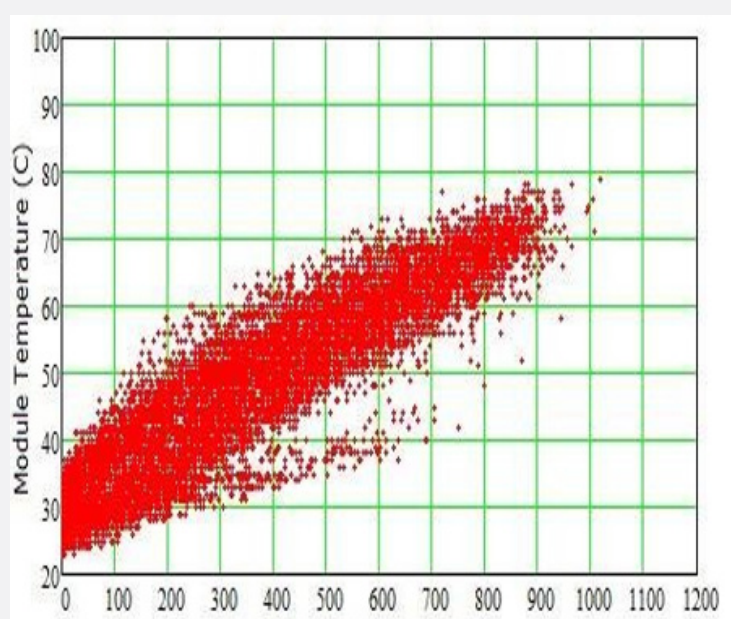

Figure 14: Irradiance vs Module temperature from reference.

Table 5 shows comprehensive data for each of the 12 months of the year. The horizontal irradiation starts low in January and February, ends low in November and December and peaks during April may June July and August. A similar trend can be observed for the diffused horizontal irradiation. In conjunction with the increased sunlight, the ambient temperature also increases and decreases accordingly. The global incident on the collector plane however is much more evenly distributed peaking at $238 \mathrm{kWh} /$ $\mathrm{m}^{2}$ in March of every year. The effective global irradiation shows the value of the irradiance after IAM and Shading losses have been deducted from it. The sixth column shows the energy output at the output of the PV array here the maximum output is $10335 \mathrm{MWh}$, which also happened in March. The second to last column displays the amount of energy injected into the grid for each month and finally the last column shows the performance ratio which peaked in winter (November, December, January and February) and dipped in summer (June and July) this is possibly due to the tilt of the panels being more optimized for year round optimum instead of summer optimum.

Table 5: Summary of Results.

\begin{tabular}{|c|c|c|c|c|c|c|c|c|}
\hline & $\begin{array}{c}\text { Global } \\
\text { Horizontal } \\
\left(\mathrm{kWh} / \mathrm{m}^{2}\right)\end{array}$ & $\begin{array}{c}\text { Diffuse } \\
\text { Horizontal } \\
\left(\mathrm{kWh} / \mathrm{m}^{2}\right)\end{array}$ & $\begin{array}{c}\text { Ambient } \\
\text { temperature } \\
\left({ }^{\circ} \mathrm{C}\right)\end{array}$ & $\begin{array}{l}\text { Global incident } \\
\text { on global coll. } \\
\text { Plane }\left(\mathrm{kWh} / \mathrm{m}^{2}\right)\end{array}$ & $\begin{array}{l}\text { Global Corr. } \\
\text { For IAM and } \\
\text { Shadings }\end{array}$ & $\begin{array}{l}\text { Energy } \\
\text { output of } \\
\text { the array } \\
\text { (MWh) }\end{array}$ & $\begin{array}{l}\text { Energy in- } \\
\text { jected into } \\
\text { the grid }\end{array}$ & $\begin{array}{l}\text { Performance } \\
\text { ratio }\end{array}$ \\
\hline January & 131.9 & 32.52 & 9.19 & 193.7 & 185.1 & 8657 & 8473 & 0.881 \\
\hline February & 144.1 & 30.87 & 11.82 & 192.5 & 183.8 & 8590 & 8411 & 0.88 \\
\hline March & 203.5 & 35.19 & 16.44 & 238 & 226.7 & 10335 & 10115 & 0.856 \\
\hline April & 221.4 & 47.4 & 21.06 & 224.8 & 213.4 & 9665 & 9467 & 0.849 \\
\hline May & 247.5 & 52.86 & 25.25 & 223.8 & 211.5 & 9520 & 9336 & 0.84 \\
\hline June & 250.3 & 45.75 & 28.35 & 213.8 & 201.6 & 8988 & 8821 & 0.831 \\
\hline July & 247.5 & 52.08 & 30.27 & 217.5 & 205.1 & 9078 & 8909 & 0.825 \\
\hline August & 231.9 & 48.03 & 30.44 & 223.8 & 211.9 & 9350 & 9167 & 0.825 \\
\hline September & 199.8 & 42.24 & 27.07 & 219.5 & 208.4 & 9253 & 9066 & 0.832 \\
\hline October & 171.6 & 38.59 & 22.83 & 217.2 & 207 & 9340 & 9152 & 0.849 \\
\hline November & 132.8 & 32.47 & 15.59 & 190.1 & 181.6 & 8404 & 8233 & 0.872 \\
\hline December & 126.3 & 25.11 & 10.65 & 195.2 & 186.8 & 8758 & 8575 & 0.885 \\
\hline Yearly & 2308.7 & 483.13 & 20.79 & 2549.9 & 2422.9 & 109937 & 107723 & 0.851 \\
\hline
\end{tabular}




\section{Economic Analysis}

In economics, a common equation for the difference between retail price and wholesale price is:

Retail Price $=2$ to $2.5 *$ Wholesale Price

This means that there is at least a $50 \%$ discount for buying in wholesale. For the purpose of this project, a conservative $25 \%$

Table 6: Cost Summary. discount is assumed. Bringing the cost of the PV panels down to 34.125 million USD, the cost of inverters down to 5.94 million USD and the cost of supporting structure to 3.457 million USD. The project lifetime in this study is 25 years. In [28] it is mentioned that the CAPEX for utility scale solar in 2019 is as low as 0.5 to $0.65 \$$ /Watt while in 2017 half the utility scale projects achieved a CAPEX of $0.8 \$$ /Watt or less. Values of different components before and after discount are shown in Table 6.

\begin{tabular}{|c|c|c|c|}
\hline Component & USD/Watt & Total (million USD) & Total after discount (million USD) \\
\hline PV module & 0.91 & 45.5 & 34.125 \\
\hline Supporting structure & 0.09 & 4.61 & 3.457 \\
\hline Inverter & 0.18 & 7.92 & 5.94 \\
\hline Total before BOS & 1.18 & 58.03 & 53.52 \\
\hline Total after BOS & & & 52.227 \\
\hline
\end{tabular}

In [29] the O\&M cost for developed countries was 10\$/ kw. The report also mentions that LCOE levels are lower in the Middle East due to the lower O\&M costs, but an exact rate was not specified. For this project $10 \$ / \mathrm{kw}$ will be used as the operations and maintenance costs. Therefore, the total yearly $0 \& \mathrm{M}$ cost is 500000 USD. The previous figures are inputted into PVsyst as can be seen in Table 6.

According to [30] in which the authors produced a comprehensive study on feed-in tariffs they concluded by saying that $0.18 \mathrm{SAR} / \mathrm{kwh}$ is the best tariff for Saudi Arabia which is equal to $0.048 \$ / \mathrm{kwh}$. Another value for the feed in tariffs found [31] is $0.0853 \$ / \mathrm{kwh}$ which is almost double the previous rate. the research in [31] is directly from a Saudi university working in conjunction with the Saudi electricity company therefore it is seen as the more accurate source and $0.0853 \$ / \mathrm{kwh}$ inserted in the tariff section of PVsyst. The energy cost was $0.024 \mathrm{USD} / \mathrm{kwh}$. Tables 7 \& 8 show some of the result of the economic simulation it shows that the payback period for the project is 6 years (year 2026) with a $315.9 \%$ return on investment (ROI) and 164 million USD net profit by the end of the project lifetime (25 years). Cummalative cash flow diagram is shown in Figure 15.

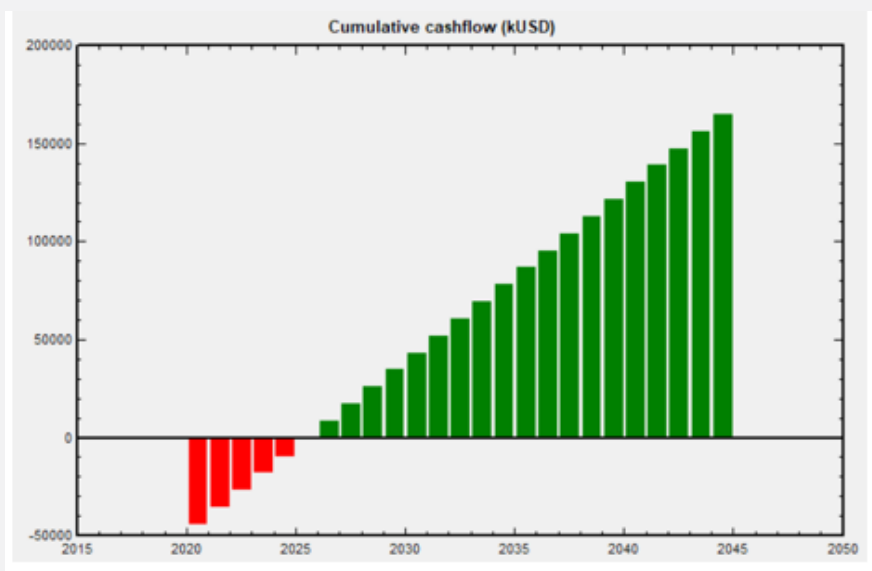

Figure 15: Cumulative Cashflow diagram.

LCOE calculation is not currently present in PVsyst but it will be added in the future according to the creators of the software. Overall, this project is very profitable and worth the investment. According to the carbon balance tab in PVsyst. By undergoing this project Saudi Arabia should be able to save more than 1.68 million tons of $\mathrm{CO}_{2}$ emissions over the project lifetime which is approximately 0.67 million tons per year as can be seen from Figure 16 and Table 9. Initially the panels and all labor and components involved in the project create a negative carbon balance but around the $1^{\text {st }}$ year of this project's operation $\mathrm{CO}_{2}$ balance turns positive and keeps on increasing until the $25^{\text {th }}$ year. 


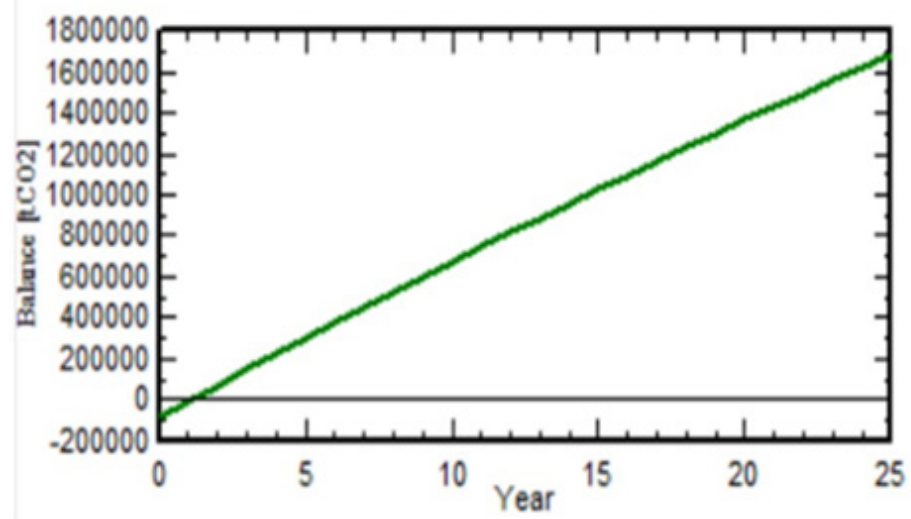

Figure 16: $\mathrm{CO}_{2}$ emission reduction.

Table 7: PVsyst Economic Analysis.

\begin{tabular}{|c|c|}
\hline Parameter & Value \\
\hline Currency & USD \\
\hline PV modules & $34,125,000$ \\
\hline Supports for modules & $3,457,120$ \\
\hline Inverters & $5,940,000$ \\
\hline BOS & $8,704,000$ \\
\hline Gross investment & $52,226,000$ \\
\hline Project lifetime & 25 \\
\hline O\&M Yearly costs & 500,000 \\
\hline Energy cost & 0.024 USD $/ \mathrm{kWh}$ \\
\hline Payback period & 6.0 years \\
\hline Net profit at end of lifetime & $164,994,000$ USD \\
\hline Return on investement & $315.90 \%$ \\
\hline
\end{tabular}

Table 8: Economic Detailed Results.

\begin{tabular}{|c|c|c|c|}
\hline Year & Profit & Cummulative profit & Return on investment (+100\%) \\
\hline 2020 & $8,689,000$ & $8,689,000$ & $36.60 \%$ \\
\hline 2021 & $8,689,000$ & $17,378,000$ & $49.30 \%$ \\
\hline 2022 & $8,689,000$ & $26,067,000$ & $66.50 \%$ \\
\hline 2023 & $8,689,000$ & $34,756,000$ & $83.20 \%$ \\
\hline 2024 & $8,689,000$ & $43,445,000$ & $99.80 \%$ \\
\hline 2025 & $8,689,000$ & $52,134,000$ & $116.50 \%$ \\
\hline 2026 & $8,689,000$ & $60,823,000$ & $133.10 \%$ \\
\hline 2027 & $8,689,000$ & $69,512,000$ & $149.70 \%$ \\
\hline 2028 & $8,689,000$ & $78,201,000$ & $166.40 \%$ \\
\hline 2029 & $8,689,000$ & $86,890,000$ & $183.00 \%$ \\
\hline 2030 & $8,689,000$ & $95,579,000$ & $199.60 \%$ \\
\hline 2031 & $8,689,000$ & $104,268,000$ & \\
\hline
\end{tabular}




\section{Trends in Technical \& Scientific Research}

\begin{tabular}{|l|l|l|l|}
\hline 2032 & $8,689,000$ & $112,957,000$ & $216.30 \%$ \\
\hline 2033 & $8,689,000$ & $121,646,000$ & $232.90 \%$ \\
\hline 2034 & $8,689,000$ & $130,335,000$ & $249.60 \%$ \\
\hline 2035 & $8,689,000$ & $139,024,000$ & $282.80 \%$ \\
\hline 2036 & $8,689,000$ & $147,713,000$ & $299.50 \%$ \\
\hline 2037 & $8,689,000$ & $156,402,000$ & $316.10 \%$ \\
\hline 2038 & $8,689,000$ & $165,091,000$ & $322.70 \%$ \\
\hline 2039 & $8,689,000$ & $173,780,000$ & $349.40 \%$ \\
\hline 2040 & $8,689,000$ & $182,469,000$ & $366.00 \%$ \\
\hline 2041 & $8,689,000$ & $191,158,000$ & $382.60 \%$ \\
\hline 2042 & $8,689,000$ & $199,847,000$ & $399.30 \%$ \\
\hline 2043 & $8,689,000$ & $208,536,000$ & $415.90 \%$ \\
\hline
\end{tabular}

Table 9: Carbon Balance.

\begin{tabular}{|c|c|}
\hline Parameter & Value \\
\hline Energy injected into grid & $107723.2(\mathrm{MWh})$ \\
\hline System lifetime & 25 years \\
\hline Annual degradation rate & $1.00 \%$ \\
\hline LCE grid & $743 \mathrm{~g} \mathrm{CO} / \mathrm{kWh}$ \\
\hline LCE system & 91759.3 tonnes $\mathrm{CO}_{2}$ \\
\hline Carbon balance (lifetime) & 1686522.057 tonnes $\mathrm{CO}_{2}$ \\
\hline Carbon balance (per year) & 67460.882 tonnes $\mathrm{CO}_{2} / \mathrm{year}^{-}$ \\
\hline Carbon balance (per kWp) & 33.975 tonnes $\mathrm{CO}_{2} / \mathrm{kWp}$ \\
\hline Carbon balance (per kWp per year) & 1.359 tonnes $\mathrm{CO}_{2} / \mathrm{kWp}^{\mathrm{year}}$ \\
\hline
\end{tabular}

\section{Conclusion}

In conclusion, Saudi Arabia plans to generate 9.5GW of its energy from renewable sources by 2023 . However, there is a lack of literature regarding the design and feasibility of a large-scale solar project in the country. This project went through different design steps with proper justification in designing a 50 MW solar farm. Site selection was carried out based on results of previous literature and using Solar GIS to find the optimum location in terms of temperature, irradiance, terrain, proximity to roads and air temperature. Then a PV module was selected from a comprehensive list of all available models in the market by filtering and sorting the data based on fill factor, efficiency, degradation rate, power density and module price. LG365Q1C-A5 was the selected PV module and Sunny central SC-2200-Us was the chosen inverter. The number of PV modules in series is 20 and in parallel is 6800 while the number of inverters is 20 . PVsyst was then used to simulate the project and the results were displayed and discussed. These results include Loss analysis, energy generated analysis and temperature performance. In the losses analysis the highest losses were $5.77 \%$ due to thermal losses followed by $3.0 \%$ losses due to soiling. Overall, the amount of useful energy harvested every month varied. Reaching its peak in March and dipping to its lowest value in January. This designed system achieved better temperature performance than a reference, receiving higher irradiance while keeping lower module temperatures. Next, an economic analysis was carried out which showed that the payback period for this project is 6 years, with a $315.9 \%$ return on investment (ROI) and 164 million USD net profit by the end of the project lifetime (25 years). Finally, $\mathrm{CO} 2$ balance analysis was reported which showed that over the project lifetime Saudi Arabia would be able to save more than 1.68 million tons of $\mathrm{CO}_{2}$ emissions.

\section{Future Work}

Further studies can be made following this one that focus on including storage options such as hydropower, hydrogen cell or batteries. Different scenarios for maximizing the power can be investigated such as adjusting the tilt angle so that it maximizes summer energy generation. Thirdly, bifacial panels or panels with axis tracking can be used to find the effect on energy harvested and the economics of the project. 


\section{References}

1. Saudi Arabia - Power (2019) export.gov Export.gov.

2. 4 factors driving renewable energy in Saudi Arabia World Economic Forum (2019).

3. Almasoud AH, Hatim MG (2015) Future of solar energy in Saudi Arabia. Journal of King Saud University - Engineering Sciences 27(2): 153-157.

4. Alotaibi D, Akrami M, Dibaj M, Javadi A (2019) Smart energy solution for an optimised sustainable hospital in the green city of NEOM. Sustainable Energy Technologies and Assessments 35: 32-40.

5. Al Garni H, Awasthi A (2017) Solar PV power plant site selection using a GIS-AHP based approach with application in Saudi Arabia. Applied Energy 206: 1225-1240.

6. Almarshoud AF (2016) Performance of solar resources in Saudi Arabia Renewable and Sustainable Energy Reviews. 66: 694- 701.

7. Solarlea.org (2019).

8. Jahangiri M, Ghaderi R, Haghani A, Nematollahi O (2016) Finding the best locations for establishment of solar-wind power stations in Middle- East using GIS: A review. Renewable and Sustainable Energy Reviews 66: 38-52.

9. Irena.org (2019).

10. Teachengineering.org (2019).

11. Kalogirou S (2014) Solar energy engineering. Amsterdam: Elsevier, Academic Press.

12. What Is the Lifespan of a Solar Panel? Engineering.com.

13. Nrel.gov (2019).

14. Jordan D, Kurtz S, VanSant K, Newmiller J (2016) Compendium of photovoltaic degradation rates. Progress in Photovoltaics: Research and Applications 24(7): 978-989.

15. PV Modules (2019) Gosolarcalifornia.ca.gov.

16. Us.sunpower.com (2019).

17. LG LG365Q1C-A5: High Efficiency LG NeON® R Module Cells: $6 \times$
10 Module efficiency: 21.1\% Connector Type: MC4 (2019) LG USA Business, LG USA.

18.370W Mono Neon R Black LG370Q1C Solar Panel 0Bills (2019) DIY Wind and solar by Solaranna.

19. Sunpower solar panel review (2019) Solar4ever.com.au.

20. LG NeON R 365W Mono Solar Panel LG365Q1C 0Bills (2019) DIY Wind and Solar by Solaranna.

21. Solar Panel Support Frames Mounting Rack Solar Structure - Buy Solar Structure (2019) Solar Panel Support Frames. Solar Mounting Rack Product on Alibaba.com.

22. Inverter Modules (2019) Gosolarcalifornia.org.

23. S 792kW SMA SC720CP Grid Tied Inverter 3 -Ph 792kW (2019) FreeCleanSolar.com.

24. Renewable energy technologies: cost analysis series (2012) Irena.org.

25. Al Garni H, Awasthi A, Wright D (2019) Optimal orientation angles for maximizing energy yield for solar PV in Saudi Arabia. Renewable Energy 133: 538-550.

26. Sunny Central datasheet (2019) Files.sma.de.

27. Hussin M, Omar A, Zain Z, Shaari S, Zainuddin H (2012) Design Impact of $6.08 \mathrm{kWp}$ Grid-Connected Photovoltaic System at Malaysia Green Technology Corporation. International journal of electrical and electronic systems research 5(8): 1-12.

28. Vartiainen E, Masson G, Breyer C, Moser D, Román ME (2019) Impact of weighted average cost of capital, capital expenditure, and other parameters on future utility-scale PV levelised cost of electricity. Progress in Photovoltaics: Research and Applications 28(6): 439-453.

29. Renewable power generation costs in 2018 Irena.org.

30. Ko W, Al-Ammar E, Almahmeed M (2019) Development of Feed-in Tariff for PV in the Kingdom of Saudi Arabia. Energies, 12(15).

31. Elshurafa A, Alsubaie A, Alabduljabbar A, Al-Hsaien S (2019) Solar PV on mosque rooftops: Results from a pilot study in Saudi Arabia. Journal of Building Engineering 25: 100809.

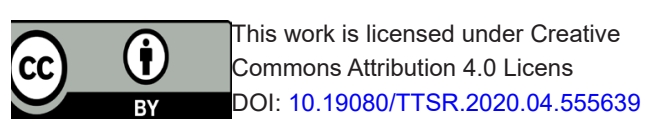

\section{Your next submission with Juniper Publishers will reach you the below assets}

- Quality Editorial service

- Swift Peer Review

- Reprints availability

- E-prints Service

- Manuscript Podcast for convenient understanding

- Global attainment for your research

- Manuscript accessibility in different formats

( Pdf, E-pub, Full Text, Audio)

- Unceasing customer service

Track the below URL for one-step submission https://juniperpublishers.com/online-submission.php 